\title{
FOOD INTOLERANCES AND ASSOCIATED SYMPTOMS IN PATIENTS UNDERGOING FOBI-CAPELLA TECHNIQUE WITHOUT GASTRIC RING
}

\author{
Intolerâncias alimentares e sintomas associados em pacientes submetidos à técnica de Fobi-Capella sem anel gástrico
}

Marcella de Arruda MOREIRA, Patrícia Ramos Maciel ESPÍNOLA,

Camila Wanderley de AZEVEDO, Cinthia Karla Rodrigues do Monte GUEDES

From a private clinic in the city of Recife, $\mathrm{PE}$, Brazil.

HEADINGS - Bariatric surgery. Feeding. Symptoms.
ABSTRACT - Background: Bariatric surgery is considered the only effective method to treat refractory obesity, and especially for those in which clinical treatment was not successful. However, the appearance of food intolerances and clinical manifestations are quite common. Aim: To identify food intolerances and associated them to symptoms in patients undergoing Fobi-Capella technique without gastric ring. Methods: This was a cross-sectional study of adult patients who had more than one year after surgery. Demographic, anthropometric, weight and preoperative height data were investigated. Nutritional status was classified according to the criteria established by the World Health Organization. It was considered food intolerance the presence of nausea, vomiting, diarrhea or bloating after eating a particular food. Results: The sample consisted of 61 patients who attended the nutritional consultation of which 26 (42.6\%) had food intolerance, mostly related to red meat $(n=12 ; 34.3 \%)$ during the first six months of operation; there was a significant difference between the periods between 0 and 6 months, and 7 to $12(p=0.02)$. Among the symptoms reported by patients, nausea was the most recurrent until the $6^{\text {th }}$ month, but without significant differences between the two periods $(p=0.06)$. Conclusion: The Fobi-Capella procedure without gastric ring promoted high frequency of intolerance to meat in general, especially for the red, chicken and fish, on this sequence; nausea was the most frequent symptom. These data suggest the need for adequate nutritional monitoring throughout the postoperative period.

\section{Correspondence:}

Marcella de Arruda Moreira

Email: marruda.moreira@gmail.com

Financial source: none

Conflicts of interest: none

Received for publication: 23/10/2014 Accepted for publication: 20/01/2015

DESCRITORES - Cirurgia bariátrica. Alimentação. Sintomas.
RESUMO - Racional: A cirurgia bariátrica é considerada o único método efetivo para tratamento da obesidade refratária e, principalmente, para aqueles em que o tratamento clínico não obteve sucesso. No entanto, o surgimento de intolerâncias alimentares e manifestações clínicas após são bastante comuns. Objetivo: Identificar intolerâncias alimentares e sintomas associados em pacientes submetidos à técnica de Fobi-Capella sem anel gástrico. Métodos: Trata-se de um estudo transversal com pacientes adultos que possuíam no máximo um ano de pós-operatório. Foram investigados dados demográficos, antropométricos, peso e estatura pré-cirúrgicos. 0 estado nutricional foi classificado de acordo com os critérios estabelecidos pela World Health Organization. Considerou-se intolerância alimentar a presença de náuseas, vômitos, diarreia ou distensão abdominal após ingestão de um alimento específico. Resultados: A amostra foi composta por 61 pacientes que compareceram a consulta nutricional dos quais $26(42,6 \%)$ apresentaram intolerância alimentar, sendo a maioria relacionada à carne vermelha $(n=12 ; 34,3 \%)$ durante os primeiros seis meses da operação, havendo redução significativa entre os períodos de 0 a 6 meses e 7 a 12 meses $(p=0,02)$. Dentre os sintomas relatados pelos pacientes, a náusea foi o mais recorrente até o $6^{\circ}$ mês, porém sem diferença estatística entre os dois períodos $(p=0,06)$. Conclusão: O procedimento de Fobi-Capella sem anel gástrico promoveu elevada frequência de intolerância às carnes em geral, principalmente para a vermelha, frango e peixe, nesta sequência; a náusea foi o sintoma mais frequente. Estes dados sugerem necessidade de acompanhamento nutricional adequado durante todo o período pós-operatório.

INTRODUCTION

G iven the significant global rise in morbid obesity, bariatric surgery has become frequent in many countries. Of all the techniques, the Rouxen-Y gastric bypass ${ }^{4}$ stands out because it is effective and has low morbidity, being considered the gold standard for the treatment of the disease ${ }^{5}$.

Despite the successful weight loss and improvement of obesity-related comorbidities, the onset of postoperative food intolerances and clinical manifestations are quite common. They are caused by many factors, such as changes in the gastrointestinal system and the slow adaptation of the body to all the changes made by surgery ${ }^{8}$. Intolerances may appear at any time. However, their intensity subsides and varies between individuals ${ }^{17}$.

Salviano et al. ${ }^{19}$ found that roughly $53 \%$ of the patients submitted to this type of surgery have postoperative food intolerances, most of them due to red 
meat (44\%), pasta/sweets (24\%), and milk (20\%). Food intolerances may be accompanied by nausea, vomiting, and dumping syndrome ${ }^{20}$.

To minimize possible complications, nutritional follow-up is necessary before and after surgery. First, care is very important to prepare the patients to the upcoming necessary changes in food habits, chewing, serving size, and meal duration ${ }^{22}$.

Postoperative nutritional follow-up is critical to avoid food intolerances, nutritional deficiencies stemming from inadequate food intake, and excessive weight loss, in addition to the much required multidisciplinary followup $^{17}$.

Hence, the objective of the present study is to identify food intolerances and associated symptoms in patients submitted to Roux-en-Y gastric bypass.

\section{METHODS}

This study was submitted to the CEP/CONEP system of the Brazilian Platform and approved by the local Human Research Ethics Committee under protocol number 06578412.0.0000.5193/2012, as required by Resolution $\mathrm{n}^{\circ} 466 / 2012$ issued by the National Health Council. A signed letter of consent provided the permission to conduct the study at a health facility. All patients signed an informed consent form before entering the study.

This cross-sectional study was conducted at a private clinic in the city of Recife, PE, Brazil. The sample consisted of male and female patients aged 20 to 58 years with or without obesity-related comorbidities submitted to Roux-en-Y gastric bypass no more than one year before the interview.

The exclusion criteria were: lactose intolerance, kidney disease, celiac disease, pregnancy, banded bypass, and refusal to join the study.

Data were collected from patients who visited the nutrition outpatient clinic between August and November 2012 either to start or continue the postoperative followup. Preoperative demographic and anthropometric data were collected. Weight and height had been measured in the last nutritional visit before surgery, allowing the calculation of preoperative body mass index (BMI). The participants' nutritional status was classified as recommended by the World Health Organization (WHO) ${ }^{24}$.

A validated self-administered, easy-to-understand and -fill out food intolerance questionnaire was used for collecting dietary data. The questionnaire consisted of objective and subjective questions for the patients to report their current eating habits. Food intolerance was defined as the presence of nausea, vomiting, diarrhea, and/or abdominal bloating after the intake of a particular food $^{12}$.

The data were saved in the software Microsoft Excel $2007 \AA$. The statistical analyses were performed by the programs SPSS (Statistical Package for Social Sciences) version 13.0 and Epi-info version 6.04. The Kolmogorov-Smirnov test investigated whether the data was normally distributed. All continuous variables presented a Gaussian distribution and were expressed as means and standard deviations (SD) or percentages, with additional calculation of the $95 \%$ confidence intervals (95\%CI).

The groups were categorized according to the time since surgery (0-6 months and 7-12 months) and compared. The categorical variables were expressed as simple frequencies and compared by Pearson's chisquare test or Fisher's exact test when necessary. The significance level was set at $5 \%$.
RESULTS

The sample consisted of 61 obese patients aged 20 to 58 years (mean age $37.9 \pm 10.3$ years) with a mean BMI of $44.1 \pm 5.2 \mathrm{~kg} / \mathrm{m}^{2}$. Most patients were women $(82 \%$; IC $70.0-90.6)$ aged 35 to 59 years (57.4\%; IC $\left.{ }_{95 \%} 44.0-69.9\right)$.

Food intolerances were investigated by food group (Table 1). Most intolerances involved meats in general and occurred in the first six months after surgery (78.9\%), significantly subsiding in the 7-12-month period $(p=0.02)$.

TABLE 1 - Distribution of the food intolerances 0-6 and 7-12 months after Roux-en-Y gastric bypass.

\begin{tabular}{|cc|c|c|c|c|c|}
\hline & \multicolumn{9}{c}{ Postoperative period } & & \multirow{2}{*}{ Food groups } \\
\cline { 2 - 6 } & $0-6$ months & \multicolumn{2}{c}{$7-12$ months } & \multirow{2}{*}{$\mathcal{*}^{*}$} & $\mathrm{p}^{* *}$ \\
\cline { 2 - 6 } & $\mathrm{n}$ & $\%$ & $\mathrm{n}$ & $\%$ & & \\
\hline Meats in general & 15 & 78.9 & 4 & 21.1 & 5.250 & 0.02 \\
\hline Grains and flours & 3 & 42.9 & 4 & 57.1 & 0.682 & 0.40 \\
\hline Legumes & 2 & 66.7 & 1 & 33.3 & 0.111 & 0.74 \\
\hline Tubers & 2 & 66.7 & 1 & 33.3 & 0.111 & 0.74 \\
\hline Milk and dairy products & 6 & 75.0 & 2 & 25.0 & 1.169 & 0.28 \\
\hline Sugar and sweets & 3 & 50.0 & 3 & 50.0 & 0.148 & 0.70 \\
\hline Deep-fried foods & 2 & 66.7 & 1 & 33.3 & 0.111 & 0.74 \\
\hline
\end{tabular}

$\mathrm{n}=$ number of patients; *Pearson's chi-square test; ** $\mathrm{p}$-valor

The foods most associated with food intolerances during the $0-6$-months period were red meat $(n=12$; $34.2 \%)$, chicken $(n=9 ; 25.7 \%)$, and fish $(n=4 ; 11.42 \%)$.

Twenty (57.1\%) and six (23.0\%) patients experienced food intolerances in the 0-6-months and 7-12 months periods, respectively.

Food intolerance-related symptoms subsided in the 7-12-months period, but the difference was not significant (Table 2).

TABLE 2 - Distribution of clinical manifestations 0-6 and 7-12 months after Roux-en-Y gastric bypass

\begin{tabular}{|c|c|c|c|c|c|c|}
\hline \multirow{3}{*}{$\begin{array}{c}\text { Clinical } \\
\text { manifestations }\end{array}$} & \multicolumn{4}{|c|}{ Postoperative period } & \multirow{3}{*}{$x^{*}$} & \multirow{3}{*}{$\mathrm{p}^{* *}$} \\
\hline & \multicolumn{2}{|c|}{$0-6$ months } & \multicolumn{2}{|c|}{ 7-12 months } & & \\
\hline & $\mathrm{n}$ & $\%$ & $\mathrm{n}$ & $\%$ & & \\
\hline Diarrhea & 1 & 50.0 & 1 & 50.0 & 0.046 & 0.83 \\
\hline Nausea & 13 & 76.5 & 4 & 23.5 & 3.513 & 0.06 \\
\hline Vomiting & 7 & 63.6 & 4 & 36.4 & 0.215 & 0.64 \\
\hline $\begin{array}{c}\text { Gastroesophageal } \\
\text { reflux }\end{array}$ & 6 & 85.7 & 1 & 14.3 & 2.596 & $0.22^{* * *}$ \\
\hline Postprandial distension & 7 & 87.5 & 1 & 12.5 & 3.416 & $0.12^{* * *}$ \\
\hline Abdominal pain & 8 & 88.9 & 1 & 11.1 & 4.287 & $0.06^{\star * *}$ \\
\hline Dumping syndrome & 3 & 60.0 & 2 & 40.0 & 0.015 & 0.90 \\
\hline
\end{tabular}

$\mathrm{n}=$ number of patients; ${ }^{*}$ Pearson's chi-square test; ${ }^{* *} \mathrm{p}$-value; ${ }^{* * *}$ Fisher's exact test

\section{DISCUSSION}

Obesity is a chronic non-communicable disease characterized by an excessive accumulation of body fat. Today it is considered a severe public health problem, reaching epidemic proportions both in developed and developing countries ${ }^{14}$. Its cause is related to complex endocrine-metabolic, genetic, socioeconomic, environmental, behavioral, and psychological interactions ${ }^{7}$.

Many diseases can be associated with obesity because of excess body fat, such as diabetes mellitus, high blood pressure, dyslipidemia, metabolic syndrome, and cardiovascular disease. All these factors can worsen health and cause premature death ${ }^{11}$. 
The mean postoperative age (37.8 years) and BMI $\left(44.1 \mathrm{~kg} / \mathrm{m}^{2}\right)$ of the study sample were similar to those reported by Bregion et al. ${ }^{1}$.

The study sample included considerably more women than men, similar to Quadros et al. ${ }^{17}$, who studied 165 patients of which 128 (77.6\%) were women. A possible justification is the unforgiving beauty standards imposed by society and the higher incidence of obese women as opposed to men in the city of Recife, datum reported by the Ministry of Health who found that $17.1 \%$ and $12.2 \%$ of women and men, respectively, living in the city were obese $^{10}$.

According to the Brazilian Family Budget Survey (POF 2008-2009), the rates of obesity increased in the adult Brazilian population in the last 35 years. The increase was significantly higher in males, going from $2.8 \%$ to $12.4 \%$, while in females it went from $8 \%$ to $16.9 \%$. Despite the high increase among men, obesity continues to prevail in women?

Most of the study sample was aged 35 to 59 years. Brazilian studies show that ageing is an important determinant of obesity, especially in women. Women gain approximately $6 \%$ of their body weight per decade. Thus, roughly $6.9 \%$ of women aged $18-24$ years are obese; this percentage almost doubles in 25-34-years (12.4\%) and almost triples in 35-44-years (17.1\%). After age 45 years, obesity in women reaches an even higher incidence, approximately $25 \%{ }^{11}$.

Twenty-six individuals (42.6\%) experienced food intolerances in the postoperative period, a slightly smaller proportion than those found by Soares \& Falcão ${ }^{21}$ (46.7\%) and Cruz \& Marimoto ${ }^{2}(46.5 \%)$, but higher than that found by Silva et al. ${ }^{20}(37.7 \%)$. High-protein foods were the least tolerated, especially red meat in the first six months after surgery $(n=12 ; 34.28 \%)$. On the other hand, intolerance to grains and flours was higher in the 7-12-months period $(n=4 ; 57.1 \%)$; but the difference was not significant $(p=0.40)$.

These data corroborate a study done with 37 obese patients followed at a university hospital: the frequency of intolerance to high-protein foods, especially red meat (35.3\%) and chicken (11.8\%), increased in the first three months after surgery. Intolerance to grains and flours, such as rice $(11.8 \%)$ and cornmeal $(14.7 \%)$, began three or more months after surgery ${ }^{13}$

Meat intolerance may stem from the significant gastric resection promoted by surgery, changing the amount of pepsin produced, an enzyme responsible for protein digestion ${ }^{9}$. On the other hand, rice intolerance may stem from impaired amylase activity due to rice hydration and gelatinization, which occur during cooking ${ }^{23}$.

The present study found very few women with legume and tuber intolerances in the two study groups, which may be justified by the low intake of high-fiber foods in the first year after surgery ${ }^{17}$.

Some patients do not tolerate lactose well since the intestinal rearrangement promoted by surgery reduces lactase production, resulting in poor lactose digestion ${ }^{3}$. Since the changes promoted by surgery make the first month after surgery the most critical period, more food intolerances occurred in the 0-6-months period.

The frequency of intolerance to sugar and sweets was the same in both study periods, and frequency to deep-fried foods was slightly higher in the first six months after surgery, but the difference was not significant. Gomes et al. ${ }^{6}$ found that patients begin to consume higher amounts of foods high in simple sugars and fats six months or more after surgery, so intolerances are more likely to occur then.
The food intolerance-related symptoms reported by the patients were diarrhea, nausea, vomiting, gastroesophageal reflux, postprandial gastric distension, abdominal pain, and dumping syndrome, all of which were more frequent in the first six months after surgery, but the difference was not significant.

Abdominal pain may be more frequent in the first months after surgery because of high food intake and inadequate chewing, impairing digestion ${ }^{18}$

Pessina, Andreoli, \& Vassallo ${ }^{16}$ found more frequent complaints of nausea and vomiting in the first six months after surgery. Mottin et al. ${ }^{15}$ reported that $48.9 \%$ of their patients experienced vomiting in the second month after surgery, coinciding with the introduction of normalconsistency foods, especially rice and meat. Another study of 69 patients found that $37.7 \%$ presented food intolerances, and the most common symptoms were vomiting (69\%) and diarrhea $(12 \%)^{20}$.

Regarding dumping syndrome, Deitel ${ }^{3}$ states that these symptoms may affect $70 \%$ of the patients, especially in the first months after surgery, corroborating the present finding that the incidence of this syndrome was higher in the $0-6$-months period $(60 \%)$, but the difference in relation to the 7-12-months period was not significant.

\section{CONCLUSION}

Roux-en-Y gastric bypass caused a high frequency of intolerance to meats in general, especially red meat, chicken, and fish, in this order. Nausea was the most frequent symptom. These data suggest the need of proper nutritional follow-up during the entire postoperative period.

\section{REFERENCES}

1. Bregion NO, Silva SA, Salvo VLMA. Estado nutricional e condição de saúde de pacientes nos períodos pré e pós-operatório de cirurgia bariátrica. Rev Bras Ciênc Saúde, ano III. 2007 Out/Dez; (14).

2. Cruz MRR, Marimoto IMI. Intervenção nutricional no tratamento cirúrgico da obesidade mórbida: resultados de um protocolo diferenciado. Rev Nutr. 2004; 17(2): 263-72.

3. Deitel $\mathrm{M}$. The change in the dumping syndrome concept. Obes Surg. 2008; 18:1622-24

4. Fancisco MC, Barella SM, Abud TG, VilarVS, Reibscheid S, Arasaki $\mathrm{CH}$, et al. Análise Radiológica das alterações gastrintestinais após cirurgia de Fobi-Capella. Radiol Bras. 2007; 40(4): 235-238.

5. Ferraz EM, Arruda PCL, Bacelar TS, Ferraz AAB, Albuquerque AC, Leão CS. Tratamento cirúrgico da obesidade mórbida. Rev Col Bras Cir. 2003 Mar/Abr; 30 (2):98-105.

6. Gomes GS, Rosa MA, Faria HRM. Perfil nutricional dos pacientes de pós-operatório de cirurgia bariátrica. Revista Digital de Nutrição. 2009 Ago/Dez; 3(5):462-476.

7. IBGE - Instituto Brasileiro de Geografia e Estatística. Pesquisa de Orçamentos Familiares 2008-2009. [acesso em: 2012 Nov 24]. Disponível em: <http://www.ibge.gov.br/home/ estatistica/populacao/condicaodevida/pof/2008_2009_ encaa/pof_20082009_encaa.pdf>.

8. Jóia-Neto, Luiz, Lopes-Junior, Ascêncio Garcia and Jacob, Carlos Eduardo Alterações metabólicas e digestivas no pós-operatório de cirurgia bariátrica. $A B C D$, arq. bras. cir. dig., Dez 2010, vol.23, no.4, p.266-269. ISSN 0102-6720

9. Kenler HA, Brolin RE, Cody RP. Changes in eating behavior after horizontal gastroplasty and Roux-en-Y gastric bypass. Am J Clin Nutr.1990; 52(1):87-92

10. Ministério da Saúde. Dados de obesidade por capital. [acesso em: 2012 Nov 24]. Disponível em: <http://portalsaude. saude.gov.br/portalsaude/arquivos/pdf/2012/Abr/10/ obesidade_100412.pdf>. 
11. Ministério da Saúde. Quase metade da população brasileira está acima do peso. [acesso em:2012 Nov25]. Disponível em: <http:// portalsaude.saude.gov.br/portalsaude/noticia/4718/162/ quase-metade-da-populacao-brasileira-esta-acima-do-peso. html>.

12.Moize V, Geliebter A, Gluck ME et al. Obese patients have inadequate protein intake related to protein intolerance up to 1 yea following Roux-en-Y gastric bypass. Obes Surg. 2003; 13:23-8

13. Moreira MA, Silva SA, Araújo CMS, Nascimento CCC. Avaliação clínico-nutricional de obesos submetidos ao Bypass Gástrico em Y de Roux. Acta Gastroenterol Latinoam. 2010 Sep; 40(3): 244-50.

14. Moreira MA, Silva SA, Nascimento CCC. Frequência de intolerância e aversão alimentar e estado nutricional de obesos submetidos à cirurgia bariátrica em um hospital universitário. Rev Bras Nutr Clínica. 2009; 24 (3 Supl):1-148.

15. Mottin CC. Tolerância alimentar no acompanhamento pósoperatório da cirurgia bariátrica: um estudo de 149 pacientes obesos mórbidos. Boletim Cirurgia da Obesidade. 2002; 3(3):45.

16. Pessina A, Andreoli M, Vassalo C. Adaptability and compliance of the obese patient to restrictive gastric surgery in the short term. Obes Surg. 2001; 11(4):459-63.

17.Quadros MRR, Savaris AL, Ferreira MV, Branco Filho AJ. Intolerância alimentar no pós-operatório de pacientes submetidos à cirurgia bariátrica. Rev Bras Nutr Clin. 2007; 22 (1): 15-9.
18. Quilici MTV. E após a cirurgia bariátrica? Rev Fac Cienc Med. 2006; 8(3): 30-2.

19.Salviano FN, Burgos MGPA, Cavalcanti AC, Cabral PC, Viana LA. Prevalência de intolerância alimentar no pós-operatório de cirurgia bariátrica. Boletim SBCB. 2004; 9:72.

20.Silva MRSB, Silva SRB, Ferreira AD. Intolerância alimentar pósoperatória e perda de peso em pacientes submetidos à cirurgia bariátrica pela técnica Bypass Gástrico. J Health Sci Inst. 2011; 29(1):41-4

21.Soares CC, Falcão MC. Abordagem nutricional nos diferentes tipos de cirurgia bariátrica. Rev Bras Nutr Clin. 2007; 22(1): 59-64.

22.Valezi AC, Brito SJ, Mali Junior J, Brito EM. Estudo do padrão alimentar tardio em obesos submetidos à derivação gástrica com bandagem em Y-de-Roux: Comparação entre homens e mulheres. Rev Col Bras Cir. 2008 Nov / Dez; 35(6).

23. White $S$, Brooks E, Jurikova L, Stubbs RS. Long-term outcomes after gastric bypass. Obes Surg. 2005; 15(2):155-63.

24.World Health Organization (WHO). Physical status: the use and interpretation of anthropometry. Technical Report Series 854. Genebra: World Health Organization; 1995. Disponível em: <http://www.who.int/childgrowth/publications/physical_ status/en/> Acessado em: 29/01/2015 
In the article "FOOD INTOLERANCES AND ASSOCIATED SYMPTOMS IN PATIENTS UNDERGOING FOBI-CAPELLA TECHNIQUE WITHOUT GASTRIC RING", with the number of DOI: /10.1590/S0102-67202015000100010 published in the periodical Arquivos Brasileiros de Cirurgia Digestiva, 28 (1): 36- 39, on page 36:

Inclusion of author:

Cinthia Karla Rodrigues do Monte Guedes 